\title{
Vitamin D Levels in Patients with Low-energy Hip Fractures
}

\author{
Jaehwi Han, MD, Youngho Cho, MD, Seungmin Jee, MD, Seongwoo Jo, MD \\ Department of Orthopaedic Surgery, Daegu Fatima Hospital, Daegu, Korea
}

Purpose: To evaluate serum 25(OH) vitamin D levels in patients with low-energy hip fractures.

Materials and Methods: Among 983 patients who underwent hip fracture surgery between August 2013 and March 2019, 732 patients were evaluated. The remaining patients were excluded due to the presence of one or more of the following: metastatic bone tumor, metabolic bone disease other than osteoporosis, fracture due to high-energy injury, atypical femoral fracture, and no blood test. We collected patient's data about age, sex male female, date of injury, a place of residence, fracture type, preinjury ambulation ability according to their Koval score, and their serum level of $25(\mathrm{OH})$ vitamin $\mathrm{D}$. The mean age was 79.3 years (60-104 years). The sample was comprised of 530 female and 202 male, of which 342 had femoral neck fractures and 390 had trochanteric fractures.

Results: Of the total 732 patients, 346 patients (47.3\%) had a 25(OH) vitamin D level of less than $10 \mathrm{ng} / \mathrm{mL}, 264$ patients (36.1\%) had scores of 10-19.9 ng/mL, 87 patients (11.9\%) had scores of 20-29.9 ng/mL, and 35 patients (4.8\%) had a level higher than $30 \mathrm{ng} / \mathrm{mL}$. Vitamin D deficiency (less than $20 \mathrm{ng} / \mathrm{mL}$ ) was present in 610 patients $(83.3 \%)$, insufficiency $(20-29.9 \mathrm{ng} / \mathrm{mL})$ was found in 87 patients $(11.9 \%)$, and 35 patients $(4.8 \%)$ had normal vitamin D levels. The differences in vitamin D concentration based on season and fracture type were statistically significant.

Conclusion: Vitamin D deficiency and inadequacy were high in patients with low-energy hip fractures, with only $4.9 \%$ of patients had normal vitamin D levels. These findings suggest that efforts should be made to maintain proper vitamin $\mathrm{D}$ concentration.

Key Words: Low energy, Hip fractures, Vitamin D

Submitted: August 14, 2020 1st revision: September 8, 2020

Final acceptance: September 18, 2020

Address reprint request to

Youngho Cho, MD

(https://orcid.org/0000-0002-1527-7761)

Department of Orthopaedic Surgery, Daegu Fatima Hospital, 99

Ayang-ro, Dong-gu, Daegu 41199, Korea

TEL: +82-53-940-7324 FAX: +82-53-954-7417

E-mail: femur1973dgmail.com

This is an Open Access article distributed under the terms of the Creative Commons Attribution Non-Commercial License (http://creativecommons.

org/licenses/by-nc/4.0) which permits unrestricted non-commercial use, distribution, and reproduction in any medium, provided the original work is properly cited.

\section{INTRODUCTION}

Vitamin D is mostly produced by sunlight and can be consumed as food like fish oils and mushrooms. In the United States, many vitamin D-fortified foods like milk, cereal, and orange juice account for most of the vitamin D intake ${ }^{1}$, but these foods are not common in Korea. Furthermore, the photobiogenesis of vitamin D3 in the skin has been reduced by modern lifestyles which include large amounts of time indoors during work hours and recreational activities, in addition to the frequent use of sunscreen and higher levels of air pollution. Vitamin D deficiency has been reported at a high rate in various popu- 
lation groups regardless of ages, races, places of residence, and disease ${ }^{2-6)}$.

Hip fracture has been recognized as the most serious consequence of osteoporosis due to its potential complications, which include chronic pain, disability, diminished quality of life, and premature death. Various efforts have been made to reduce osteoporotic hip fractures, including vitamin D administration ${ }^{7}$. Vitamin D deficiency causes muscle weakness and increases the risk of falls and hip fractures ${ }^{8,9)}$, and some reports found that the administration of vitamin $\mathrm{D}$ is sufficient to reduce the risk of falls by more than $20 \%{ }^{10}$. Therefore, vitamin D deficiency may be a risk factor for osteoporotic hip fractures. For this reason, special attention should be paid to vitamin $\mathrm{D}$ deficiency in patients with osteoporosis. Although there are some controversies over what level of vitamin D is considered normal, several studies in different countries reported a prevalence of vitamin D deficiency in $50 \%$ to $94.2 \%$ of patients with hip fractures ${ }^{11-17}$. Due to limited data on a relationship between vitamin D and hip fractures in Korea, the aim of the current study was to evaluate the vitamin D status in patients with low-energy hip fractures in Korea specifically.

\section{MATERIALS AND METHODS}

Between August 2013 and March 2019, a retrospective radiographic review was conducted of all patients who suffered from a proximal femoral fracture. During this period, 983 patients with proximal femoral fractures were found. We excluded patients with metastatic bone tumor, metabolic bone disease other than osteoporosis, fracture due to high-energy injury, atypical femoral fracture, and any records missing a blood test for $25(\mathrm{OH})$ vitamin $\mathrm{D}$. After exclusions, a total of 732 patients with hip fractures were enrolled in this study.

We collected demographic data on age, sex, date of injury, place of residence, fracture type, preinjury ambulation ability according to Koval score ${ }^{18)}$ and serum level of $25(\mathrm{OH})$ vitamin D.

All blood samples were taken in the emergency room during the preoperative evaluation. Vitamin D was measured by chemiluminescent microparticle immunoassay on the Architect-I2000 system (Abbott Diagnostics, Abbott Park, IL, USA). Vitamin D deficiency was defined as a serum $25(\mathrm{OH})$ vitamin D lesser than $20 \mathrm{ng} / \mathrm{mL}$, relative insufficiency was defined as 20 to $29 \mathrm{ng} / \mathrm{mL}$, and patients were categorized as having sufficient vitamin D if levels were more than $30 \mathrm{ng} / \mathrm{mL}^{2}$.
Chi-squared tests were used for comparison between categorical variables, and a Mann-Whitney $U$-test was used for continuous variables. Statistical significance was set at a $P$-value less than 0.05 . Data analysis was performed using SPSS ver. 22.0 (IBM Corp., Armonk, NY, USA).

Institutional Review Board of the Daegu Fatima Hospital approval was obtained prior to beginning this study (DFE20ORIO078-R1).

\section{RESULTS}

A total of 732 patients with a low-energy hip fracture were enrolled in this study. The mean age of the patients was 79.3 years (60-104 years). There were 84 patients in their 60s, 276 in 70s, 314 in 80s, and 58 in their 90s or older. There were 530 females $(72.4 \%)$ and 202 males. Sixhundred ten patients $(83.3 \%)$ lived at home prior to their

Table 1. Basic Demographics of Patients

\begin{tabular}{|c|c|}
\hline Characteristic & Value \\
\hline Age (yr) & $79.3(60-104)$ \\
\hline $60-69$ & $84(11.5)$ \\
\hline $70-79$ & 276 (37.7) \\
\hline $80-89$ & $314(42.9)$ \\
\hline$\geq 90$ & $58(7.9)$ \\
\hline \multicolumn{2}{|l|}{ Sex } \\
\hline Female & $530(72.4)$ \\
\hline Male & $202(27.6)$ \\
\hline \multicolumn{2}{|l|}{ Residence } \\
\hline Home & $610(83.3)$ \\
\hline Nursing hospital & $50(6.8)$ \\
\hline Nursing home & $72(9.8)$ \\
\hline \multicolumn{2}{|l|}{ Preinjury ambulation ability } \\
\hline $\begin{array}{l}\text { Independent community } \\
\text { ambulatory (Koval I) }\end{array}$ & 408 (55.7) \\
\hline $\begin{array}{l}\text { Community ambulatory with } \\
\text { cane/walker (Koval II) }\end{array}$ & 137 (18.7) \\
\hline $\begin{array}{l}\text { Independent household } \\
\text { ambulatory (Koval III) }\end{array}$ & $118(16.1)$ \\
\hline $\begin{array}{l}\text { Household ambulatory with } \\
\text { cane/walker (Koval IV) }\end{array}$ & $39(5.3)$ \\
\hline Activity confined to room (Koval V) & $12(1.6)$ \\
\hline Non-ambulator (Koval VI) & $18(2.5)$ \\
\hline \multicolumn{2}{|l|}{ Season } \\
\hline Spring (March-May) & 175 (23.9) \\
\hline Summer (June-August) & $162(22.1)$ \\
\hline Fall (September-November) & $193(26.4)$ \\
\hline Winter (December-February) & $202(27.6)$ \\
\hline \multicolumn{2}{|l|}{ Fracture type } \\
\hline Extra-capsular fracture & 390 (53.3) \\
\hline Intra-capsular fracture & $342(46.7)$ \\
\hline
\end{tabular}

Values are presented as mean (range) or number (\%). 
injury, 50 were in a nursing hospital setting, and 72 were in nursing homes. Five-hundred forty-five patients $(74.5 \%)$ were community ambulators, 157 were household ambulators, 12 were activity confined to their rooms, and 18 were

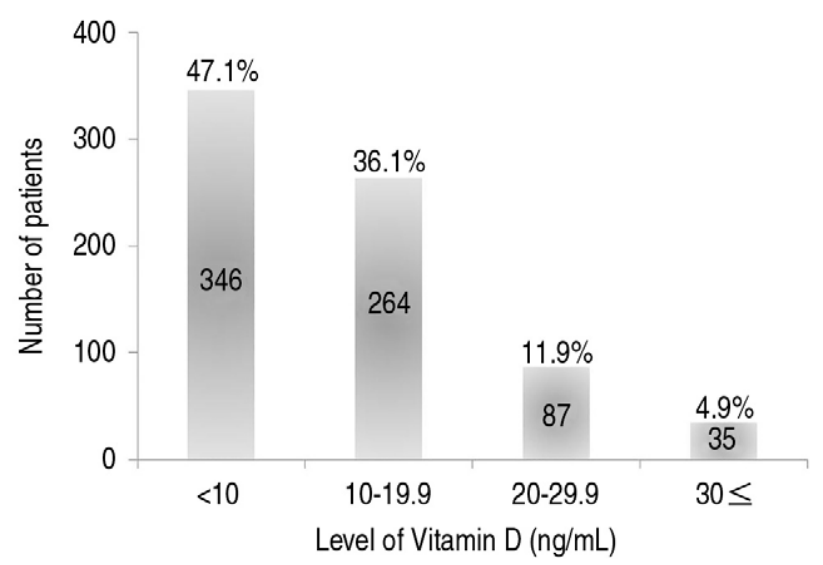

Fig. 1. Distribution of 732 patients according to level of vitamin D.

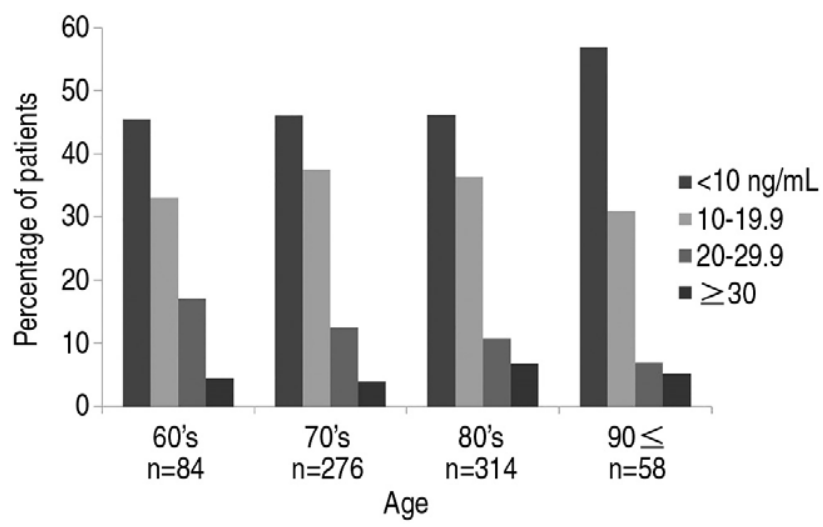

Fig. 3. Distribution of patients according to vitamin D level by age.

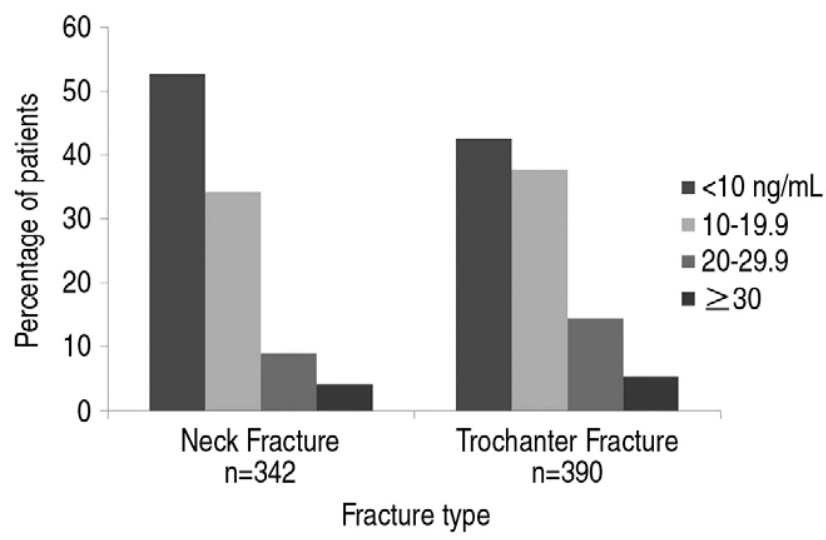

Fig. 5. Distribution of patients according to vitamin D level by type of fracture. non-ambulatory. One-hundred seventy-five hip fractures occurred in the spring, 162 in the summer, 193 in the fall, and 202 in the winter. Three-hundred ninety patients (53.3\%) had an extra-capsular fracture (Table 1).

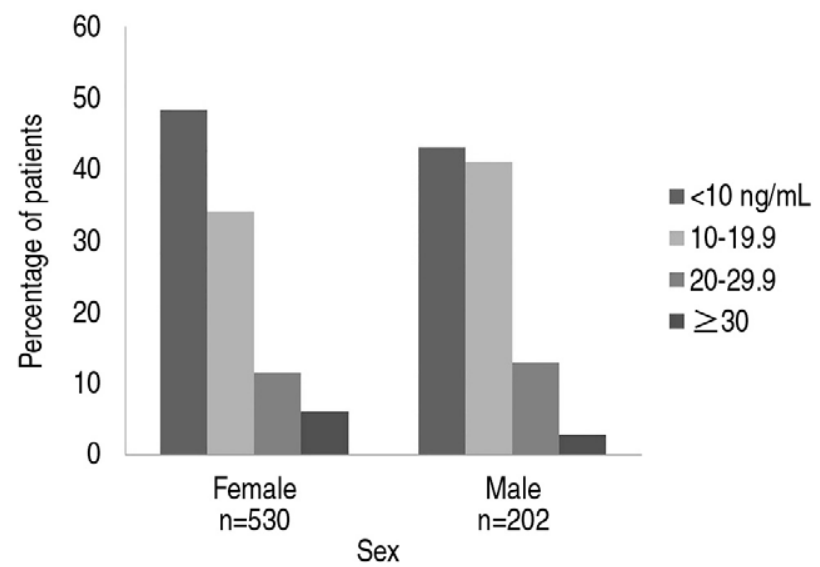

Fig. 2. Distribution of patients according to vitamin D level by sex.

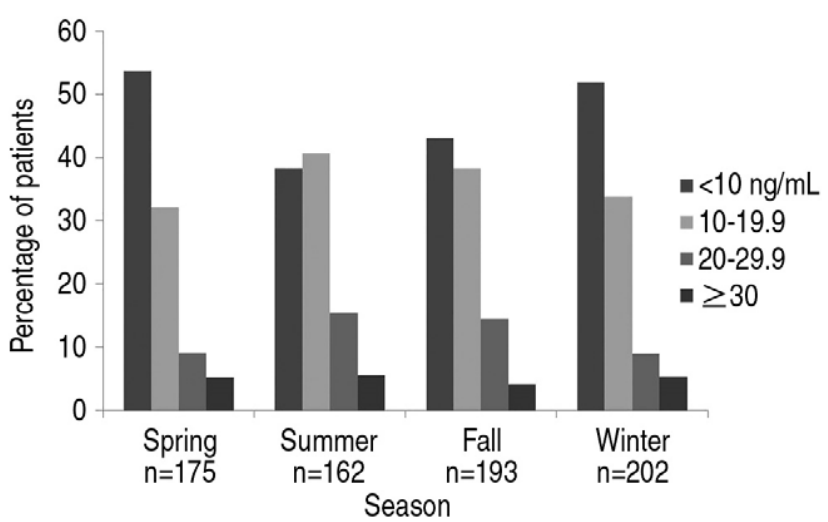

Fig. 4. Distribution of patients according to vitamin D level by season.

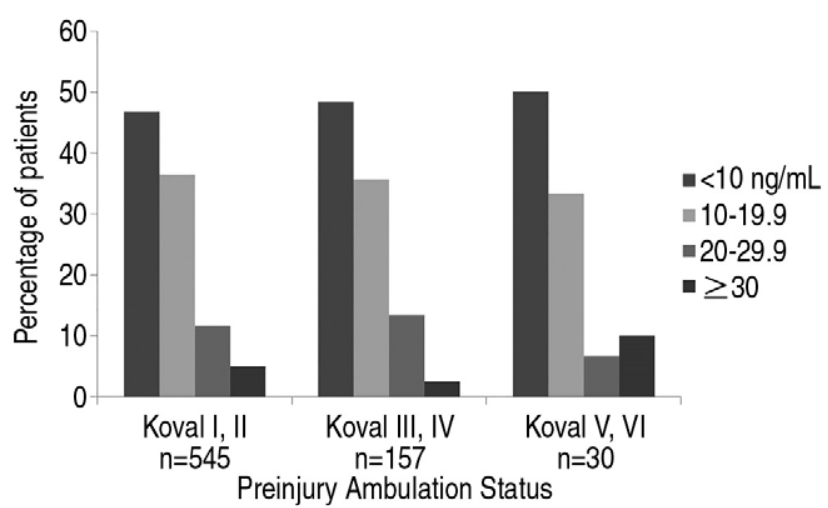

Fig. 6. Distribution of patients according to vitamin D level by preinjury ambulation. 
The average vitamin D level overall was $12.9 \mathrm{ng} / \mathrm{mL}$ (2$61.7 \mathrm{ng} / \mathrm{mL})$. Of the total 732 patients, 346 patients $(47.1 \%)$ had a $25(\mathrm{OH})$ vitamin D level of less than $10 \mathrm{ng} / \mathrm{mL}, 264$ patients $(36.1 \%)$ had a level between $10-19.9 \mathrm{ng} / \mathrm{mL}, 87$ patients $(11.9 \%$ ) had levels between $20-29.9 \mathrm{ng} / \mathrm{mL}$, and 35 patients $(4.9 \%)$ had a level above $30 \mathrm{ng} / \mathrm{mL}$. Vitamin D deficiency (less than $20 \mathrm{ng} / \mathrm{mL}$ ) was present in 610 patients $(83.2 \%)$, insufficiency $(20-29.9 \mathrm{ng} / \mathrm{mL})$ was present in 87 patients $(11.9 \%)$, and normal levels (more than $30 \mathrm{ng} / \mathrm{mL}$ ) were found in only 35 patients $(4.9 \%)$ (Fig. 1).

Each figure shows the distribution of patients according to vitamin D level by sex, age, season, type of fracture, preinjury ambulation status, and residential setting (Fig. 2-7).

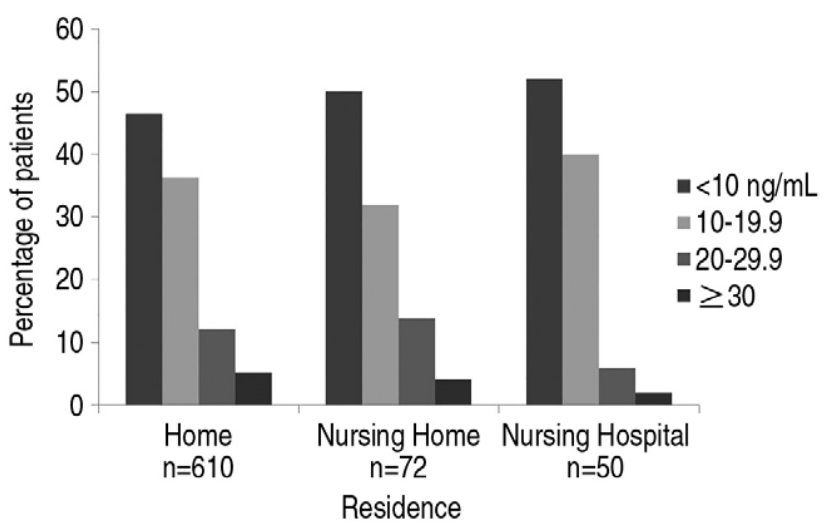

Fig. 7. Distribution of patients according to vitamin D level by residence.
Subgroup analysis found no statistically significant differences in vitamin D concentration according to age, sex, residence, or preoperative ambulation status. However, the differences in vitamin $\mathrm{D}$ concentration according to season and type of fracture were found to be statistically significant (Table 2).

\section{DISCUSSION}

Vitamin D deficiency is a worldwide health care problem in elderly populations, similar to osteoporosis. In particular, Korea is one of the countries with the highest reports of vitamin D deficiency ${ }^{19)}$. Though the term 'Vitamin D deficiency' is used commonly, debates on optimal blood level of $25(\mathrm{OH})$ vitamin $\mathrm{D}$ continue to call into question specifically what levels are categorized as deficient. The World Health Organization defined a deficiency as a $25(\mathrm{OH})$ vitamin $\mathrm{D}$ concentration of $10 \mathrm{ng} / \mathrm{mL}$ or less, and insufficiency as $20 \mathrm{ng} / \mathrm{mL}$ or less ${ }^{20)}$. The American Institute of Medicine defines deficiency as a level of $12 \mathrm{ng} / \mathrm{mL}$ or less, and 20 $\mathrm{ng} / \mathrm{mL}$ as normal ${ }^{21)}$. Typically, most experts define vitamin $\mathrm{D}$ deficiency as less than $20 \mathrm{ng} / \mathrm{mL}$ of serum $25(\mathrm{OH})$ vitamin D and relative insufficiency between 21 to $29 \mathrm{ng} / \mathrm{mL}$ with normal levels greater than $30 \mathrm{ng} / \mathrm{mL}^{8,22-27)}$. The ideal serum level of vitamin $\mathrm{D}$ has been determined as a one sufficient to maintain parathyroid hormone (PTH) within a normal range as vitamin $\mathrm{D}$ deficiency can cause secondary hyperparathyroidism. Though plateau levels of PTH can

Table 2. Subgroup Analysis of Vitamin D Level

\begin{tabular}{|c|c|c|c|c|}
\hline Variable & & No. of patients & Level of vitamin $D(\mathrm{ng} / \mathrm{mL})$ & $P$-value \\
\hline \multirow[t]{2}{*}{ Sex } & Female & $530(72.4)$ & $12.8 \pm 8.4$ & 0.505 \\
\hline & Male & $202(27.6)$ & $13.2 \pm 7.3$ & \\
\hline \multirow[t]{4}{*}{ Age (yr) } & $60-69$ & $84(11.5)$ & $14.2 \pm 7.9$ & 0.151 \\
\hline & $70-79$ & 276 (37.7) & $12.7 \pm 8.2$ & \\
\hline & $80-89$ & $314(42.9)$ & $13.1 \pm 8.0$ & \\
\hline & $\geq 90$ & $58(7.9)$ & $11.1 \pm 8.1$ & \\
\hline \multirow[t]{4}{*}{ Season } & Spring & $175(23.9)$ & $11.3 \pm 7.3$ & 0.017 \\
\hline & Summer & $162(22.1)$ & $14.5 \pm 8.4$ & \\
\hline & Fall & $193(26.4)$ & $13.7 \pm 8.2$ & \\
\hline & Winter & $202(27.6)$ & $12.5 \pm 8.2$ & \\
\hline \multirow[t]{2}{*}{ Diagnosis } & Neck fracture & $342(46.7)$ & $12.2 \pm 7.6$ & 0.027 \\
\hline & Trochanter fracture & $390(53.3)$ & $13.5 \pm 8.5$ & \\
\hline \multirow[t]{3}{*}{ Ambulation } & Koval I, II & $545(74.5)$ & $13.1 \pm 8.3$ & 0.405 \\
\hline & Koval III, IV & $157(21.4)$ & $12.2 \pm 7.2$ & \\
\hline & Koval V, VI & $30(4.1)$ & $13.0 \pm 8.9$ & \\
\hline \multirow[t]{3}{*}{ Residence } & House & $610(83.3)$ & $13.1 \pm 8.2$ & 0.348 \\
\hline & Nursing home & $72(9.8)$ & $12.6 \pm 7.9$ & \\
\hline & Nursing hospital & $50(6.8)$ & $11.4 \pm 6.9$ & \\
\hline
\end{tabular}

Values are presented as number $(\%)$ or mean \pm standard deviation. 
be reached at various serum levels of $25(\mathrm{OH})$ vitamin $\mathrm{D}$, in general, plateau levels are found when vitamin $\mathrm{D}$ is more than $30 \mathrm{ng} / \mathrm{mL}^{26-29)}$. Given these findings, the current study adopted the criteria recognized by most experts, defining sufficient or normal levels of $25(\mathrm{OH})$ vitamin $\mathrm{D}$ as more than $30 \mathrm{ng} / \mathrm{mL}$.

The current study found that vitamin D deficiency $(<20$ $\mathrm{ng} / \mathrm{mL}$ ) was present in $83.2 \%$ of patients, with $11.9 \%$ categorized as insufficient (20-29.9 ng/mL), and only $4.9 \%$ met the criteria of sufficient vitamin D level of more than 30 $\mathrm{ng} / \mathrm{mL}$. The percentage of patients with vitamin $\mathrm{D}$ deficiency in the present study was higher when compared to other studies $^{13-17)}$. In the current study, the average vitamin D concentration of males and females was $13.2 \mathrm{ng} / \mathrm{mL}$ and 12.8 $\mathrm{ng} / \mathrm{mL}$, respectively. Park et al..$^{30)}$ reported an average vitamin D concentration in the general Korean population over 65 years old of $20 \mathrm{ng} / \mathrm{mL}$ in men and $18.3 \mathrm{ng} / \mathrm{mL}$ in women. Similar to the current study, patients with hip fractures were found to have a greater vitamin D deficiency.

Hip fracture is the most catastrophic consequence of osteoporosis due to the high morbidity and mortality rates associated with this type of fracture. The ultimate goal of osteoporosis treatment is prevention of fracture. Vitamin D and fracture risk reduction were not relevant in meta-analysis without considering vitamin $\mathrm{D}$ dose $\mathrm{e}^{31)}$, but in a recent meta-analysis, high-dose vitamin D supplementation ( $\geq$ 800 international unit [IU] daily) was somewhat favorable in the prevention of hip fracture and any non-vertebral fracture in persons 65 years of age or older ${ }^{32}$. A similar metaanalysis found that a daily low dose of 400 IU vitamin D may not be clinically effective in preventing falls in the elderly whereas a high dose of 800 ID vitamin D plus calcium was associated with a lower risk of falling ${ }^{8}$. The Korean Society for Bone and Mineral Research recommends that a blood $25(\mathrm{OH}) \mathrm{D}$ concentration should be at least $20 \mathrm{ng} / \mathrm{mL}$ to prevent osteoporosis and $30 \mathrm{ng} / \mathrm{mL}$ or more may be needed to treat osteoporosis and prevent falls in osteoporosis patients ${ }^{33}$.

In the subgroup analysis, vitamin D concentration in summer was significantly higher than in other seasons. Although there have been reports of decreased vitamin D synthesis in the skin with age ${ }^{34}$, our results indicate that sunlight exposure is one of the most important factors to maintain adequate vitamin $D$ levels, even in older adults in agreement with many other studies ${ }^{13-16}$. As the patient's sunlight exposure could not be measured directly, it was confirmed indirectly using the Koval score, though our results did not show a significant relationship between Koval score and vitamin $\mathrm{D}$ concentration. Other variables such as age, sex, and residence were not associated with vitamin D deficiency. Vitamin D levels were significantly higher in patients with trochanter fractures than in patients with femur neck fractures, but no clear reason for this relationship was apparent.

Important sources of vitamin D are sunlight exposure and vitamin D intake through diet and supplements. Vitamin D-fortified foods are not common in Korea, therefore sunlight exposure and vitamin D supplements are important for the maintenance of vitamin D concentration. Korea is located from $33^{\circ}$ to $38^{\circ}$ north latitude and has four distinct seasons. Additionally, most of Korean have a type IV skin according to Fitzpatrick classification ${ }^{35}$. There is no research on the specific solar exposure time to properly maintain vitamin D levels in the blood at these latitudes. However, based on studies conducted in other latitudes, an appropriate sun exposure time for the synthesis of 1,000 IU of vitamin $\mathrm{D}$ is around 10 minutes in the summer solstice, 40 minutes in the winter solstice, and approximately 15 minutes in the spring equinox at noon, with $25 \%$ exposure for individuals with type IV skin (based on Fitzpatrick classification) which is most common in Korea ${ }^{36}$.

The current study had some limitations. We were unable to determine if patients took vitamin D supplements or not before admission which may have influenced blood levels. An additional limitation is the lack of an agreed-upon level for vitamin D deficiency worldwide, impacting reports of the prevalence of vitamin D deficiency and insufficiency based on how the cutoff value was determined. Finally, circulatory fluctuation, diet, kidney, liver disease, or other diseases that could affect vitamin D levels were not considered in this study. Despite these limitations, this study is the largest to date on the prevalence of vitamin D deficiency in elderly hip fracture patients in Korea playing an important role in the treatment of patients at this population in the future.

\section{CONCLUSION}

Vitamin D deficiency and inadequacy were high in Korean patients with low-energy hip fractures in and only $4.9 \%$ of patients showed normal blood vitamin D levels. Efforts to maintain adequate levels of vitamin $\mathrm{D}$ in the blood through proper sun exposure and vitamin D supplements are needed in patients at risk of hip fractures in Korean populations. 


\section{CONFLICT OF INTEREST}

The authors declare that there is no potential conflict of interest relevant to this article.

\section{REFERENCES}

1. Hill KM, Jonnalagadda SS, Albertson AM, Joshi NA, Weaver CM. Top food sources contributing to vitamin D intake and the association of ready-to-eat cereal and breakfast consumption habits to vitamin D intake in Canadians and United States Americans. J Food Sci. 2012;77:H170-5.

2. Holick MF. Vitamin D deficiency. N Engl J Med. 2007;357: 266-81.

3. Mithal A, Wahl DA, Bonjour JP, et al. Global vitamin D status and determinants of hypovitaminosis D. Osteoporos Int. 2009;20:1807-20.

4.Cashman KD, Dowling KG, Škrabáková Z, et al. Vitamin D deficiency in Europe: pandemic? Am J Clin Nutr. 2016;103: 1033-44.

5. Ganji V, Zhang X, Tangpricha V. Serum 25-hydroxyvitamin $D$ concentrations and prevalence estimates of hypovitaminosis $D$ in the U.S. population based on assay-adjusted data. J Nutr. 2012;142:498-507.

6. Choi HS, Oh HJ, Choi H, et al. Vitamin D insufficiency in Korea--a greater threat to younger generation: the Korea National Health and Nutrition Examination Survey (KNHANES) 2008. J Clin Endocrinol Metab. 2011;96:643-51.

7. Chapuy MC, Arlot ME, Duboeuf F, et al. Vitamin D3 and calcium to prevent hip fractures in elderly women. $N$ Engl J Med. 1992;327:1637-42.

8. Bischoff-Ferrari HA, Giovannucci E, Willett WC, Dietrich T, Dawson-Hughes B. Estimation of optimal serum concentrations of 25-hydroxyvitamin $D$ for multiple health outcomes. Am J Clin Nutr. 2006;84:18-28.

9. Cauley JA, Lacroix AZ, Wu L, et al. Serum 25-hydroxyvitamin $D$ concentrations and risk for hip fractures. Ann Intern Med. 2008;149:242-50.

10. LLim YW, Kim YS. The medical treatment of osteoporosis. J Korean Hip Soc. 2009;21:211-8.

11. Institute of Medicine. Dietary reference intakes for calcium and vitamin D. Washington, DC: Institute of Medicine; 2010.

12. Dawson-Hughes B, Mithal A, Bonjour JP, et al. IOF position statement: vitamin D recommendations for older adults. Osteoporos Int. 2010;21:1151-4.

13. Nurmi I, Kaukonen JP, Lüthje P, et al. Half of the patients with an acute hip fracture suffer from hypovitaminosis $D$ : a prospective study in southeastern Finland. Osteoporos Int. 2005;16:2018-24.

14. Moniz C, Dew T, Dixon T. Prevalence of vitamin D inadequacy in osteoporotic hip fracture patients in London. Curr Med Res Opin. 2005;21:1891-4.

15.LeBoff MS, Kohlmeier L, Hurwitz S, Franklin J, Wright J, Glowacki J. Occult vitamin D deficiency in postmenopausal US women with acute hip fracture. JAMA. 1999;281:1505-11.

16. Ramason R, Selvaganapathi N, Ismail NH, Wong WC, Rajamoney GN, Chong MS. Prevalence of vitamin d deficiency in patients with hip fracture seen in an orthogeriatric ser- vice in sunny singapore. Geriatr Orthop Surg Rehabil. 2014;5: 82-6.

17. Lee GH, Lim JW, Park YG, Ha YC. Vitamin D deficiency is highly concomitant but not strong risk factor for mortality in patients aged 50 year and older with hip fracture. J Bone Metab. 2015;22:205-9.

18. Koval KJ, Skovron ML, Aharonoff GB, Meadows SE, Zuckerman JD. Ambulatory ability after hip fracture. A prospective study in geriatric patients. Clin Orthop Relat Res. 1995; 310:150-9.

19. Lips P, Hosking D, Lippuner K, et al. The prevalence of vitamin D inadequacy amongst women with osteoporosis: an international epidemiological investigation. J Intern Med. 2006;260: 245-54.

20. WHO Scientific Group on the Prevention and Management of Osteoporosis. Prevention and management of osteoporosis: report of a WHO scientific group. Geneva: World Health Organization; 2003.

21. Committee to Review Dietary Reference Intakes for Vitamin $D$ and Calcium; Ross AC, Taylor CL, Yaktine AL, Cook HD, Institute of Medicine (U.S.). Dietary reference intakes for calcium and vitamin D. Washington, DC: National Academies Press; 2011.

22. Holick MF. High prevalence of vitamin D inadequacy and implications for health. Mayo Clin Proc. 2006;81:353-73.

23. Malabanan A, Veronikis IE, Holick MF. Redefining vitamin D insufficiency. Lancet. 1998;351:805-6.

24. Thomas MK, Lloyd-Jones DM, Thadhani RI, et al. Hypovitaminosis D in medical inpatients. N Engl J Med. 1998;338:777-83.

25. Heaney RP, Dowell MS, Hale CA, Bendich A. Calcium absorption varies within the reference range for serum 25-hydroxyvitamin D. J Am Coll Nutr. 2003;22:142-6.

26. Dawson-Hughes B, Heaney RP, Holick MF, Lips P, Meunier PJ, Vieth R. Estimates of optimal vitamin D status. Osteoporos Int. 2005;16:713-6.

27. Holick MF, Binkley NC, Bischoff-Ferrari HA, et al. Evaluation, treatment, and prevention of vitamin D deficiency: an Endocrine Society clinical practice guideline. J Clin Endocrinol Metab. 2011;96:1911-30.

28. Vieth R, Ladak Y, Walfish PG. Age-related changes in the 25-hydroxyvitamin $D$ versus parathyroid hormone relationship suggest a different reason why older adults require more vitamin D. J Clin Endocrinol Metab. 2003;88:185-91.

29. Holick MF, Siris ES, Binkley N, et al. Prevalence of Vitamin $D$ inadequacy among postmenopausal North American women receiving osteoporosis therapy. J Clin Endocrinol Metab. 2005; 90:3215-24

30. Park JH, Hong IY, Chung JW, Choi HS. Vitamin D status in South Korean population: seven-year trend from the KNHANES. Medicine (Baltimore). 2018;97:e11032.

31. Boonen S, Lips P, Bouillon R, Bischoff-Ferrari HA, Vanderschueren D, Haentjens P. Need for additional calcium to reduce the risk of hip fracture with vitamin $d$ supplementation: evidence from a comparative metaanalysis of randomized controlled trials. J Clin Endocrinol Metab. 2007; 92:1415-23.

32. Bischoff-Ferrari HA, Willett WC, Orav EJ, et al. A pooled analysis of vitamin $D$ dose requirements for fracture prevention. N Engl J Med. 2012;367:40-9.

33. Kim KM, Choi HS, Choi MJ, Chung HY. Calcium and vita- 


\section{Hip \& Pelvis}

Hip Pelvis 32(4): 192-198, 2020

min D supplementations: 2015 position statement of the Korean Society for Bone and Mineral Research. J Bone Metab. 2015; 22:143-9.

34. MacLaughlin J, Holick MF. Aging decreases the capacity of human skin to produce vitamin D3. J Clin Invest. 1985; 76:1536-8.
35. Fitzpatrick TB. The validity and practicality of sun-reactive skin types I through VI. Arch Dermatol. 1988;124:869-71.

36. Webb AR, Engelsen O. Calculated ultraviolet exposure levels for a healthy vitamin D status. Photochem Photobiol. 2006; 82:1697-703. 